\section{A REVIEW OF BYZANTINE STUDIES AND ARCHITECTURAL HISTORIOGRAPHY IN TURKEY TODAY (1)}

\author{
Şule KILIÇ YILDIZ
}

Received: 05.08.2010; Final Text: 18.10.2011

Key Words: Byzantine studies; cultural policies; architectural historiography.

1. This paper is a preliminary part of my Ph.D. dissertation which deals with the history of Byzantine Studies and Byzantine architectural historiography in Turkey in the context of the cultural policies of the nationstate from the early Republican Period to the present. I would like to express my gratitude to my thesis advisor Prof. Dr. Suna Güven for her encouragement and valuable comments.

2. See for example, papers presented at the International symposium of "Contemporary Perceptions of Byzantium" on 19-21 November, 2009, the İstanbul Studies Centre at Kadir Has University.

3. For a history of the discipline and institutional developments in Turkey, AltanErgut and Turan-Özkaya (2009).

4. For example, Bozdoğan and Necipoğlu, (2007).

\section{INTRODUCTION}

In recent years there has been an increase in studies dedicated to various aspects of the Byzantine legacy and the representation of Byzantium in history books, letters, cinema, art, even science and music in Turkey (2). However, there is still no comprehensive study focusing on the historiography of Byzantine architecture in Turkey. This article will provide a review of Byzantine Studies in Turkey from the early Republican period up to the present with a particular focus on architectural historiography. Studies in architectural historiography are late-comers to the academic scene since architectural history as an autonomous discipline itself is relatively new in Turkey (3). Historiographical studies in Turkey usually focus on early Republican and late Ottoman architecture (4). Nevertheless, there are some important studies for the history of Byzantine Studies in Turkey. As example, Semavi Eyice's “Türkiye'de Bizans Sanatı Araştırmaları ve İstanbul Üniversitesinde Bizans Sanatı" ["Studies on Byzantine Art in Turkey and Byzantine Art in İstanbul University"] published in 1973 is a leading study providing a vast bibliography for studies in Byzantine history, art history and archaeology from the late 19th century to the 1970s. In his “Türkiye' de Bizans Mimarisi Hakkındaki Yabancı Araştırmaların Kısa Tarihçesi” ["A Brief History of Foreign Studies on Byzantine Architecture in Turkey"] (1976), he also provides a bibliography of archaeological studies in Turkey carried out by foreign archaeologists from the late nineteenth century to the 1945. Yıldız Ötüken in her "Türkiye'de Bizans Sanatı" ["Byzantine Art History in Turkey"] (2003) briefly describes some of the excavations in Byzantine archaeology and mentions current art history departments teaching Byzantine art history in Turkey. The latest study is by Engin Akyürek, titled "Byzantine Art History in Modern Turkey"(2010). Akyürek provides a review of the history of Byzantine studies in Turkey from the late nineteenth century to the present by adding recent developments in scholarship, the 
5. Akyürek, (2010). I am indebted to Prof. Dr. Engin Akyürek for providing me with a copy of this paper before its publication.

6. For a detailed history of early studies in Byzantine architecture, Eyice (1976).

7. For an evaluation of the British interpretation of Byzantine architecture in the 18th and 19th century, Crinson, (1996).

8. For an evaluation of the ways in which late Ottoman historians approached Byzantine history and culture, Ursinus (1986), (1987), (1988). establishment of important research institutions and the current situation of the field (5).

As for studies in the field of history, Nevra Necipoğlu provides a brief information on the history of studies of Byzantine history in Turkey in her "Türkiye'de Bizans Tarihçiliğinin Dünü, Bugünü ve Sorunları" ["The Past, the Present and the Problems of the Study of Byzantine History in Turkey"] (2003). She states that there are primarily three barriers in studying Byzantine history in Turkey. These include the difficulty of teaching the Greek language, the lack of library facilities, and the ideological barrier namely 'the rejection of the Byzantine cultural legacy in Turkey'. Another historian, Melek Delilbaşı, also provides a summary of studies in Byzantine history by Turkish scholars from the late nineteenth century to today, in her paper "The Present and Future of Byzantine Studies in Turkey" (2005). The latest study is a paper presented at the International symposium "Contemporary Perceptions of Byzantium" on 19-21 November, 2009 in İstanbul also by Nevra Necipoğlu, "Byzantine Studies in Turkey: Contemporary Trends in Historical Scholarship".

\section{LATE NINETEENTH AND EARLY TWENTIETH CENTURIES}

Western travelers and explorers in the 18th and 19th centuries sponsored by their governments or learned societies were the first to record the existence of Christian monuments of Anatolia. In the twentieth century, archaeologists, art historians, and historical geographers who made excursions to different regions of Anatolia in order to study the archaeological and architectural remains of ancient and Christian civilizations provided important information and the first visual documentaries, according to Kalas (2004, 101-102). Charles Texier (18021871), Aguste Choisy (1841-1909), Joseph Strzygowski (1862-1941), Gertrude L. Bell (1868-1926), Sir William Ramsay (1851-1939), and Guillaume de Jerphanion (1877-1948) were some of the scholars who made excursions to Anatolia and studied Byzantine architectural remains during the late 19th and early 20th centuries (6). Although early explorations of Anatolia in the eighteenth and nineteenth centuries provided a general view and visual sources, they had paid almost no attention to history, culture and context. They usually had an orientalist approach which was very common at that time (7). Studies in the second half of the twentieth century, on the other hand, show that scholars began to develop more systematic and comprehensive methods of study. Their studies were usually comparative in method. They provide plans and photographs of the buildings with the purpose of providing the first descriptions of the early Christian and Byzantine remains in Anatolia (Kalas, 2004, 112-6).

In the Ottoman Empire, on the other hand, the study of Byzantine history began at the end of the 19th century and early 20th century. Mainly drawing on Gibbon's The Decline and Fall of the Roman Empire and Pierre Greneier's L'empire Byzantine, historians of the late Ottoman Empire such as Ahmed Midhat Efendi, Necip Asım and Mehmed Arif incorporated Byzantine history into their general history, particularly comparing the Byzantine Empire with the Ottoman Empire in order to reveal the successes of the Ottoman Empire (8). Byzantine architectural monuments were first studied by Celal Esad Arseven (1875-1971) who was also one of the first Turkish art historians. Being a member of the Muhâfaza-i Âsâr-i Atîka Encümen-i Dâimîsi (Committee for the Preservation of Historic Works) and appointed as a professor of architectural history at the Academy of 


\section{CONSTANTINOPLE}

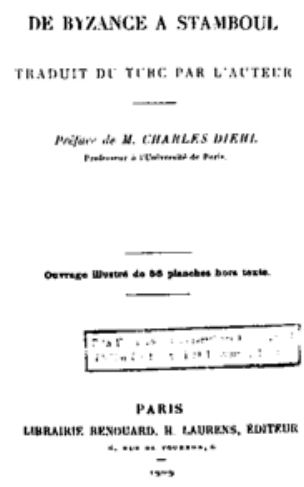

Figure 1. Celal Esad Arseven, Constantinople, de Byzance á Stamboul, (book cover).

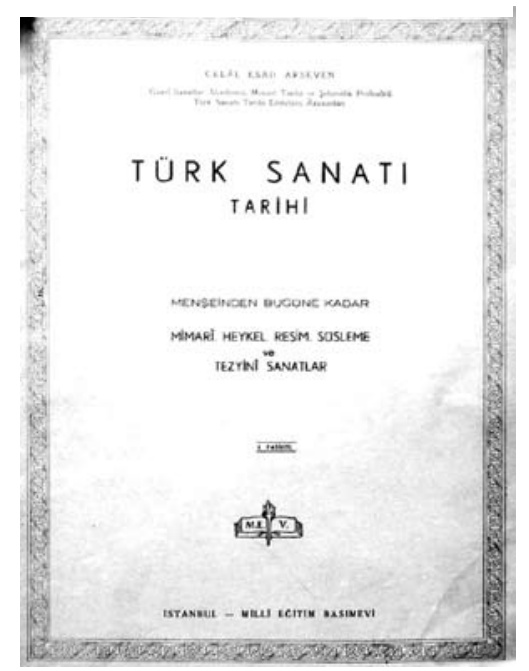

Figure 2. Celal Esad Arseven, Türk Sanatı, (book cover).
9. There have been a number of important scholarly studies examining the role of archaeological investigations in the formation of national identity and the perception of "cultural legacy" during the early Republican period. Özdoğan, (1998a), (1998b), (2004); Özdemir (2003); Pulhan, (2004); Tanyeri-Erdemir (2006), are but some.

10. For a detailed investigation of "Turkish History Thesis" with reference to Turkish History Congress and history textbooks, Ersanl1-Behar (1992); for the role of archaeology in the formation of "Turkish History Thesis", Atakuman, (2008).
Fine Arts in İstanbul, his book Constantinople, de Byzance á Stamboul, was published in 1909 (Figure 1). The other study of the Byzantine monuments of İstanbul was one by Mehmed Ziya Bey who was also a member of Muhâfaza-i Âsâr-i Atîka Encümen-i Dâimîsi. He published İstanbul ve Boğaziçi, Bizans ve Osmanl Medeniyetlerinin Asar-ı Bakiyesi in 1920 in Ottoman Turkish. Before that, he wrote a monograph on the Kariye Camii Şerifi [Chora Church] in 1908 (Mehmed Ziya, 2004; Eyice, 1993, 121-6).

\section{THE EARLY REPUBLICAN PERIOD (1923-1950)}

One of the most problematic issues regarding the construction of Turkish history in the Republican period is the question of how to integrate the Byzantine past. As is well known, archaeology and history often play important roles in the creation of a nation-state from the remains of multi-ethnic, multi-lingual, and multi-religious empires (Anderson, 1991; Hobsbawm, 1990). After the declaration of the Republic in 1923, in creating a nation-state from the remains of Ottoman Empire, history and archaeology played a pivotal role. Like other nationalisms, the Turkish Republic initiated or greatly supported archaeological excavations and the establishment of national museums to search for the roots of the Turks in connection to those earliest Anatolian civilizations (9). The Turkish Historical Society founded on June 4, 1930 was commissioned to investigate the roots of Turkish history. In this ideological context, the Turkish History Thesis, which was formulated in a book titled Türk Tarihinin Ana Hatları [Outlines of Turkish History], published in 1930. One of the basic endeavors of the Turkish History Thesis was to embrace the early civilizations of Anatolia breaking off ties with recent Ottoman and Islamic past (10). The role of the Byzantine legacy in the construction of Turkish national identity and in the definition of "national legacy" has remained a difficult and contested issue. While some of the scholars emphasized "the rejection of the Byzantine cultural legacy" as one of the most important reasons for the scarcity of Byzantine studies in Turkey (Necipoğlu, 2003, 111; Kuban et al., 1999), some others do not agree that there has been a discrimination against the Byzantine cultural legacy (Özdoğan,1998b, 202; Akyürek, 2010). One possible reason for neglecting the Byzantine cultural legacy might be the nature of the Turkish History thesis constructed during the early Republican period, embracing more of the ancient civilizations of Anatolia than the recent Ottoman and Byzantine past. What is more, the adoption of Byzantine heritage as an integral part of Greece and the incorporation of the Byzantine past into Modern Greek historiography at the end of the 19th century (Mango, 1984; Katsaridou and Biliouri, 2007) might have caused this relative exclusion of Byzantium from the definition of the cultural legacy of the newly founded Turkish Republic.

In line with this emergent nationalist historiography during the early years of the Republic, a new kind of discourse was produced in writing art and architectural history in Turkey. This was basically the assertion of Turkish art and architecture's "unique, innovative and evolving" character distinct from other Islamic and eastern arts (Bozdoğan, 2002, 262-265). This new scholarship in writing architectural history is best represented in Celal Esad Arseven's Türk Sanatı [Turkish Art] published in 1928 (Figure 2). In contrast to his earlier book Constantinople, de Byzance á Stamboul in which he handled together Byzantine and Ottoman architectural monuments, in the latter Arseven emphasizes the rational, formally pure and evolutionary character of Turkish art and architecture. Byzantine architecture, on the other hand, 
is mentioned in different parts of the book. The first is on the relations between Seljuk and Byzantine art. At the beginning, he describes Byzantine art and architecture as formed by three components: Greek culture, Christianity and Eastern influences. Arseven acknowledges that there were exchange and mutations between Byzantine and Seljuk architecture, but at the end he attributes these features to a common source, which was Asia (Arseven, 1984, 36, 57). He also emphasizes that the exchanges between these two were restricted to architectural methods and techniques. He says, "The Byzantines moved away from the beauty of ancient Greek art, as they were closer to the East, and adopted an artificial aesthetic taste" (in his phrase "yapmacık bir sanat zevki"; Arseven, 1984, 58).

In the chapter on Ottoman architecture, he again mentions Byzantine architecture. But this time, he does not accept the exchange between the two. He says, "Ottoman artists had very different perspectives from those of the Byzantines. Ottoman architecture had no relations with the diseased gloominess of Byzantine architecture" (in his phrase "hastalıklı hüzün"; Arseven, 1984, 83).

Arseven provides a periodical categorization of the historical development of Turkish art and architecture during the Ottoman period based on stylistic definitions, which had an effect on the later works of historians in Turkey. Accordingly, the "Bursa style" constitutes the very early period of Ottoman reign in the fourteenth century. Although he acknowledges some encounters between the local people of Byzantium and the Ottomans in Bursa and İznik in this early period of Byzantium, he also emphasizes the unique character of Ottoman Turkish architecture as distinct from both Seljuk and Byzantine architecture (Arseven, 1984, 147).

The efforts of Arseven to find an origin and a history of evaluation are best understood in the context of studies rooted in the "Turkish Historical Thesis." Besides his collaboration on Committee for the Preservation of Historic Works, he was part of the committee searching for the origin of Turkish history and culture in the Turkish Historical Foundation and Turkish Language Foundation (Altınyıldız, 2007, 288) Moreover, the departure point of Arseven's study was a critique of orientalist historians, who, he argued, ignored the uniqueness of Turkish art and architecture by classifying them indiscriminately under a single Islamic category (AltanErgut, 2007, 166-9).

The other study, whose departure point was a reaction similar to that of Arseven, is Fuad Köprülü's Bizans Müesseselerinin Osmanlı Müesseselerine Tesiri [The Impact of Byzantine Institutions on Ottoman Institutions] published in 1931. Köprülü states at the beginning of his book that all the contemporary western European Byzantinists, Ottomanists and scholars of Islamic history such as Rambaud, Diehl, Gibbons, Kramers, and Ducange asserted that Ottomans simply borrowed and inherited Byzantine institutions and the genius behind Ottoman state building was this Roman-Byzantine institutionalism. Against these views, he develops a very comprehensive comparative method claiming that rather than the Byzantines, Ottoman institutions had emerged from the Turco-Islamic heritage beginning on one side from the Sassanids, Abbasids, Samanids, Great Seljuks and Seljuks of Rum and on the other side from the preIslamic Turkish heritage (Köprülü, 2003).

At the same time, in line with the "Turkish Historical Thesis" a kind of "national archaeological campaign" was started for the purpose of 


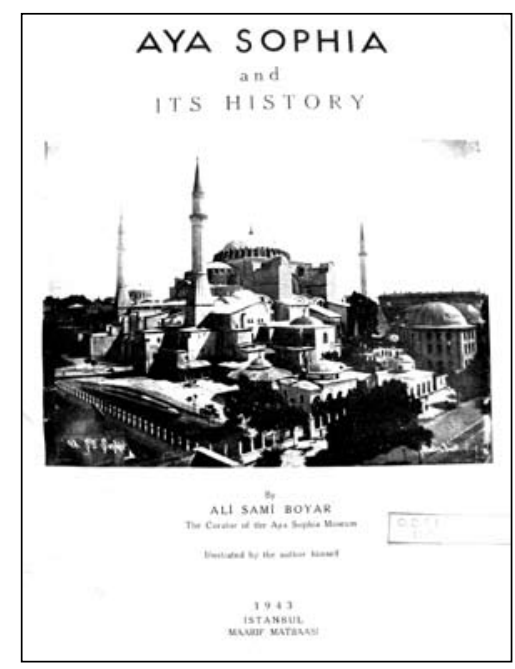

Figure 3. Ali Sami Boyar, Aya Sophia and Its History, (book cover). providing material remains in support of ideology, embracing ancient Anatolian civilizations. Ekrem Akurgal, Halet Çambel (Classical Archaeology), Sedat Alp (Hititology), Afif Erzen, Arif Müfid Mansel, and Halil Demircioğlu (Ancient History), and Suat Baydır (Classical Philology) were some of the students sent for graduate education in archaeology and ancient history to several European countries. Similarly scholars from Germany, Austria, Czechoslovakia, were invited to Turkey to study and teach in different areas (Pulhan, 2004, 169-174).

Among the archaeologists and historians whom the state sent to Europe for education, there was no scholar to study Byzantine architecture. However, there were important archaeologists, historians, and art historians -including important Byzantinists- among the scholars who were invited to study Byzantine art and archaeology and teach in the universities of Turkey (Akyürek, 2010:208). One of them was Thomas Whittemore, who was an American scholar, archaeologist and the founder of the Byzantine Institute of America; he worked in the study of the preservation of the Hagia Sophia mosaics in 1931, which was converted into a museum by a directive of Mustafa Kemal Atatürk in 1934 and in the restoration of Kariye Camii (Chora Church) in the 1940s, which was also transformed into a museum after restoration in 1948. During these years, studies in Byzantine archaeology were carried out by these foreign archaeologists and art historians. For example, D. Talbot Rice worked in the Bodrum Camisi (Myrelaon Church), Casson in the Fenari İsa Camisi (Lips Monastery), A.M.Schneider in the Byzantine churches in İznik (Eyice, 1973, 381-3). The archaeological excavations and study of Arif Müfid Mansel, working at the Archaeological Museum in İstanbul, in the Balaban Ağa Mescidi, an unknown Byzantine chapel converted into mesjid is noted as the first study in a Byzantine building carried out by a Turkish scholar in 1930's. (Mansel, 1933). Aziz Ogan, Rüstem Duyuran, Nezih Firatll, Necati Dolunay were other Turkish scholars, also working at the Archaeological Museum, who carried out archaeological studies in Byzantine buildings and published monographs on some of the Byzantine churches in İstanbul during this

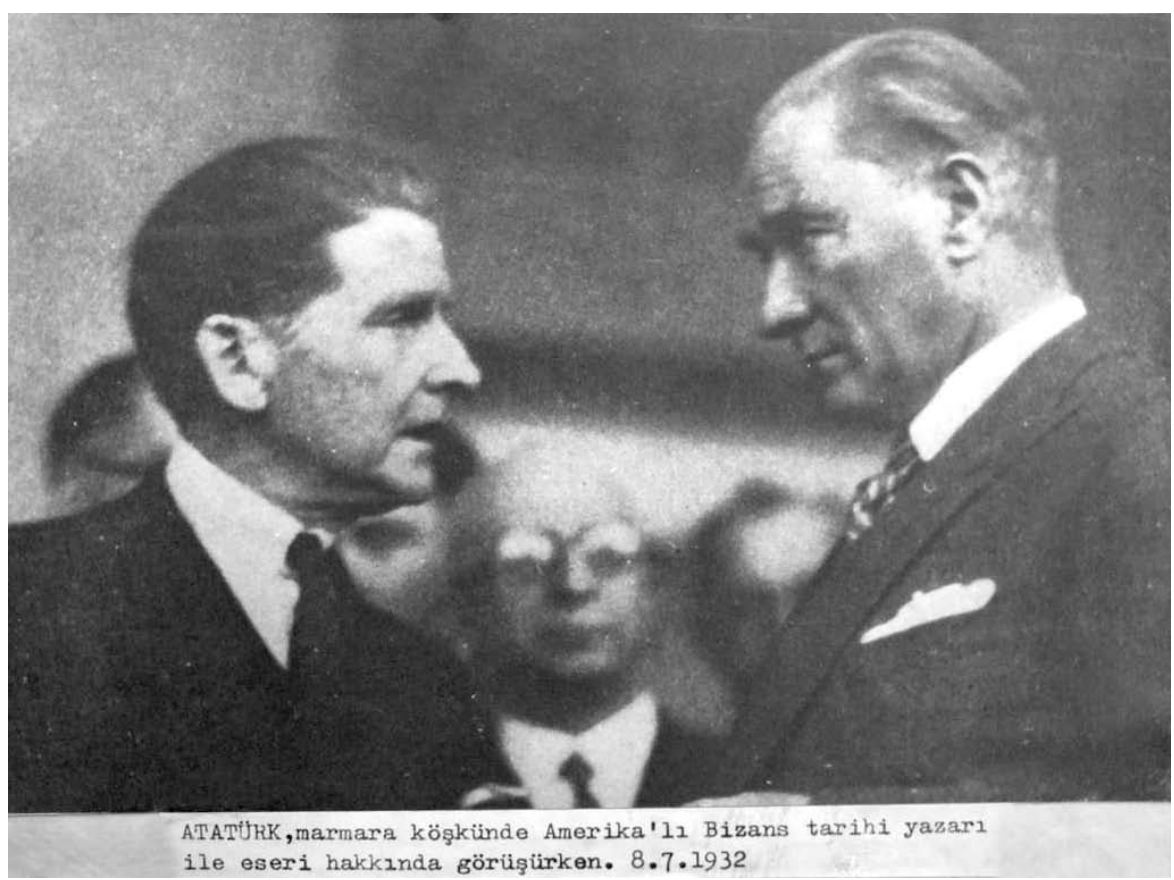

ATATfhK, marmara köskïnde Amerika'll Bizans tarihi yazarı
Figure 4. Thomas Whittemore and Atatürk (Milli Kütüphane, Atatürk Belgeliği). 
period (Eyice, 1973, 383). Ali Sami Boyar, working at the Hagia Sophia Museum, published a monograph on this building (Figure 3).

Mustafa Kemal Atatürk's personal interest in the studies of Whittemore is evident in a photograph taken in Marmara Kiosk on July 8, 1932 showing them together in conversation (Figure 4). Another instance showing Atatürk's interest in Byzantine studies is retold by Afet İnan. Accordingly, since Atatürk could not visit the archaeological studies in Vize, Tekirdağ by Arif Müfid Mansel due to illness in autumn of 1938, he wanted these archaeological findings of the excavation to be brought to Dolmabahçe Palace. After seeing them he remarked: "Go on with excavations. You will find much more of the cultural heritage of our country" (İnan, 1939, 243246; Çı̆, 2009, 33).

Studies in the area of Byzantine history were more productive than those in archaeology and architectural history in this period. While some of these were translations of Byzantine history books into Turkish (Diehl's The History of Byzantine State) by Tevhik Bıyıkoğlu (1937), Cevdet Yularkıran (1939), (Vasiliev's The History of the Byzantine Empire) by Arif Müfid Mansel (1943), there were also original studies in Byzantine history by Akdes Nimet Kurat (1933) and Şerif Baştav (1947) (Delilbaşı, 2005, 63-72). One of the most striking among these is a book Bizans Tarihi: Şarki Roma Imparatorluğu (395-1453) written by the historian Reşad Ekrem Koçu, published in 1934 as part of a series "History Books for Kids" (Koçu, 1934; Akyürek, 2010).

\section{FROM 1950 TO $1970 S$}

In 1953, the 9th International Byzantine Congress took place in Thessalonica; the foreign ministry of Turkey sent an invitation to host the 10th congress in İstanbul. Muzaffer Ramazaoğlu, the director of Ayasofya Museum who carried out excavations at the north site of Hagia Eirene, had presented a paper in the 8th Congress which had taken place in Palermo and two papers in the 9th International Byzantine Congress in Thessalonica. The 10th International Byzantine Congress took place in İstanbul in 1955. Among 115 contributors presenting papers in the conference, there were nine Turkish scholars from the disciplines of history, art history and archaeology including Tayyib Okiç, Şerif Baştav, Halil İnalcık, Zeki Velidi Togan, Ekrem Hakkı Ayverdi, Semavi Eyice, Feridun Dirimtekin, Mükerrem Usman Anabolu, and Nezih Firatlı (11).

A survey of papers presented at the Turkish History Congresses organized by the Turkish Historical Society during these years reveals that the number of papers related to Byzantine history, architecture or archaeology was very limited. Many of these papers were reports of excavations of Byzantine sites and monuments carried out by museum archaeologists such as Aziz Ogan $(1948,1952)$, Necati Dolunay (1948), Muzaffer Ramazanoğlu (1952), and Nezih Furatlı (1960), who worked for the İstanbul Archaeological Museum and the Ayasofya Museum. Apart from these excavation reports two papers were noteworthy as their titles suggest as examinations of Byzantine art and architecture in relation to Turkish / Islamic art and architecture. One of them is Ali Sami Boyar's "Türk ve Bizans Mimarisine Dair Bir Mukayese", ["A Comparative Study of Byzantine and Turkish Architecture"] in 1948. The other is Semavi Eyice's "Bizans-İslam-Türk Sanat Münasebetleri" ["The Relationships between Byzantine, Islamic and Turkish Art"] in 1960. However, both authors in 
their respective papers attempted to disprove a commonly held argument among some western scholars that Ottoman-Turkish architecture is a mere imitation of Byzantine architecture. Eyice also points out the effect of the Islamic architecture on Byzantine architecture.

The other important development during these years was the establishment of a certificate program in Byzantine art history within the department of Art History at İstanbul University. Here, Steven Runciman, a Byzantine historian, gave lectures on Byzantine art during 1941-44. Later, Ernst Diez, the chair of the department, gave lectures on the subject until 1949. In 1950, Philip Schweinfurth, a specialist on Byzantine art, began teaching in the program of Art History and Aesthetics, founded in the same year. From 1956 onwards, the lectures began to be given by a Turkish scholar, Semavi Eyice, who had been an assistant at the department at that time. In 1964, Byzantine Art History was founded as an independent program separate from the department of Aesthetics and Art History (Eyice, 1973, 412-3).

During this period, Semavi Eyice was the leading scholar in Byzantine art and architecture (12). His Ph.D. thesis "Byzantine Monuments in Side" was written in 1952. In 1963 he published Son Devir Bizans Mimarisi: Istanbul'da Palaiologos Devri Anttlar, [The Late Byzantine Architecture in İstanbul] the first book by a Turkish scholar to cover a period of Byzantine architecture, although it was confined to İstanbul and religious buildings only. In this book, Eyice investigated Byzantine churches and monasteries by dividing them into types based on ground plans such as with one nave, cross-insquare, and trefoil plan. He also evaluated 'general characteristic features' of late Byzantine architecture and its provincial ecoles, and tried to construct a chronology. He emphasized the revivalism in cultural and artistic life of Byzantium during this period, and labeled it as a "Renaissance," despite political and military retreat. He also devoted attention to "the relations between Late Byzantine architecture and early Ottoman architecture". In this evaluation, he seems to follow Arseven by deemphasizing continuity between these two (Eyice, 1980, 41). The other book published in 1971, Karadă̆ (Binbirkilise) ve Karaman Çevresinde Arkeolojik Incelemeler, [Archaeological Researches in the Karaman Region and One Thousand and One Churches] is based on archaeological investigations of Karaman, Madenşehir and Değle örenyeri. After surveying the material remains of these regions, he describes the stylistic features of the churches and monasteries peculiar to central Anatolia and discusses the origins of some the architectural elements (Eyice, 1971).

Doğan Kuban was one of the first architectural historians in Turkey who was interested in Byzantine architecture, although his major area was Turkish-Ottoman-Islamic architectural history and restoration (13). Kuban studied Byzantine architecture at the Dumbarton Oaks Research Centre, Washington in 1963. He prepared a catalog for "Anadolu'daki Hiristiyan Yapıları" ["Christian Buildings in Anatolia"] but he did not publish it (Yıldırım, 2007, 168). Instead, he mentioned Byzantine architecture in the context of influences on Anatolian Turkish architecture in his thesis for professorship, Anadolu Türk Mimarisinin Kaynak ve Sorunları [The Problems and Origin of the Anatolian Turkish Architecture]. It was published first in

12. For a bibliography of Prof. Dr. Semavi Eyice, Abbasoğlu and Belli (1992).

13. For a bibliography of Prof. Dr. Doğan Kuban, see Ahunbay and Mazlum, (1996); a more recent bibliography is provided at the end of the book by Yildirım (2007). 1965. For the first time in this book, he suggested possible links between Anatolian Turkish architecture and that of Armenia, Georgia, Byzantine, Syria and Iran, while examining the fundamental problems surrounding the Anatolian architecture of the twelfth and thirteenth centuries. His examination of Byzantine architecture is based on origins and interactions 
between Christian forms, methods and construction techniques and Anatolian Turkish architecture (Kuban, 1965, 72-6). Later, he mentions the problems of writing about Byzantine and Armenian interactions in Anatolian Turkish architecture due to the mainstream ideologies in the discipline of art history during that time (Yıldırım, 2007, 171-3). His later study on Byzantine architecture is a monograph, which is based on archaeological and restoration studies he carried out with the Byzantinist L. Striker between the years 1966-76 at Kalenderhane Mosque, where previously three Byzantine churches had existed (Striker and Kuban, 1997). For the studies at Kalenderhane, he had to study Byzantine archaeology in İstanbul and he went to the Dumbarton Oaks a second time to study Byzantine archaeology. All these studies resulted in the "Byzantine" chapter in his Istanbul an Urban History: Byzantion, Constantinopolis, İstanbul in 1996.

The approach of Metin Ahunbay to the study of Byzantine architecture, who began to work at the İstanbul Technical University upon completing his Ph.D. on Byzantine architecture in Germany, has been slightly different from that of other scholars because of his emphasis on the material and structural techniques of an architectural building in the field (14). He studied every part of the architectural elements in detail. Similar to Kuban, being an architect, he was also interested in the restoration work on many Byzantine buildings in İstanbul. Some examples are, "Conservation Works at İstanbul Land Walls", and the "Study and Restoration of the Zeyrek Camisi in İstanbul". The reason for his great interest in material and techniques might be derived from his dealing with the restoration of the buildings. Consequently, his studies in architectural history went hand-in-hand with his restoration works. What is more, he carried out excavations in "Dara-Anastasiopolis" and surveys in "The Thousand and One Churches" in the Karaman region (15).

During the 1970s and 1980s Yıldız Demiriz, Ayla Ödekan, Yıldız Ötüken, Ebru Parman, M.İhsan Tunay, Zeynep Mercangöz were other scholars beginning the study of Byzantine art and architecture at the departments of art history in Hacettepe Universty, Anadolu University, and Ege University. Today, Byzantine art and architecture is studied in 16 universities in Turkey. Except for İstanbul Technical University and Middle East Technical University, it is incorporated into the departments of art history. While a number of scholars study the ceramics, coins, metal objects, painting and decoration, the study of architecture has been increasing in recent years. These studies are usually based on field studies, surveys and excavations (16).

14. For a bibliography of Prof. Dr. Metin Ahunbay, see Ögel, (2004).

15. For "Binbirkilise (Karaman) ve Ayatekla (Silifke) Yüzey Araştırması", see the volumes of "Araştırma Sonuçları Toplantısı", for "Dara-Anastasiopolis Antik Kenti", the volumes of "Kazı Sonuçları Toplantısı", Kültür ve Turizm Bakanlığı, Kültür Varlıkları ve Müzeler Genel Müdürlüğ̈̈, Ankara.

16. For recent developments and the current situation of the field as well as for the name of scholars studying in Byzantine art and architecture in Turkish Universities, Akyürek (2010).

17. I borrowed this term from Striker (2001).

\section{TOWARD A “NEW AGE” IN BYZANTINE ARCHITECTURAL HISTORY (17)}

Cyril Mango has identified four different approaches used sometimes in isolation or in combination in studying Byzantine architecture in Europe and America. The first approach is "typological" in which materials accumulated from different regions are classified according to ground plan, elevation, system of support, decorative elements, masonry, etc. (Mango, 1991, 40-4) The typological approach usually goes hand in hand with the style analysis, which is also the product of formal analysis through identification, codification and description of the aesthetic qualities of a building. Although the analysis of artworks solely in terms of style no longer dominates the field of art history, it is still an important tool in 
the construction of the narratives of architectural history because of its emphasis on the chronological development of ornament and reinforcing the notion of progress and development (Arnold, 2006, 232).

The second approach is "symbolic", in which the architecture of a church can be interpreted through cosmological symbols which prevailed in the medieval mind. The third approach is "functional" in which different types of buildings are associated with different functions. Different from the typological, the use for which a building was intended and the intentions of the patron are important. The last approach that Mango identified is "social and economic" in which changes and developments are explained by taking into account social and economical factors. In addition to these four, Mango mentions another, the most prevalent in recent years, the archaeological approach, which is based on a detailed examination of architectural remains in context (Mango, 1991, 40-4).

An examination of studies of Byzantine architecture in Turkey also shows that until recent years, the typological approach had been the most common approach. In the early stages of Byzantine studies in Turkey, the primary purpose was to collect as many materials as possible, and then to classify and describe them according to formal criteria. Thus, the typological approach went hand in hand with the establishment of geographical schools or ecoles, and the style analysis of buildings.

Each of these approaches to the study of Byzantine architecture has certain advantages and disadvantages. The typological approach was derived from the well-known art historian Joseph Strzygowski (1862-1941), whose work was characterized by reliance on formal comparisons and the study of origins of constructive processes in architecture (i.e. the vault and the cupola). Despite its contributions to the description, classification, and to the construction of a chronology for Byzantine architecture, the typological approach has many shortcomings. Firstly, such a total reliance on formal comparisons has led to the ignorance of historical context. One example of the shortcomings of the typological approach comes from the excavation at Kalenderhane. As Striker emphasizes the findings at Kalenderhane pose important questions about the writing of Byzantine architectural history in general, particularly in relation to the mainstream conception of change and development of Byzantine architecture with regard to the evolution of the building types. The Main Church in Kalenderhane had been dated to the mid-ninth century based on its building type. According to this evolutionary, typological chronology, it was a transitional building of the cross-domed type coming between the centralized domed church of the Justinianic age and the new types of the so-called Middle Byzantine renaissance, four-column cross-in-square type. However, more detailed archaeological excavation and investigations have revealed that the church is dated to the end of the twelfth century, not to the mid-ninth century! Moreover, the discovery of two earlier churches, with a timber roofed basilica augmented the problem. Because the timber roofed basilica supposedly went out of fashion at the beginning of the 6th century, the re-appearance of this type in the centre of Constantinople in the late sixth and again in the late seventh century could not be explained with the idea of centre and periphery or metropolitan and provincial, and shows the need for a reconsideration of the established premises for the history of Byzantine architecture (Striker, 2001, 107-16).

A second problem with the typological approach is the evaluation of Byzantine architecture with the criteria of western models for medieval 
architecture. The evolutionary template of western medieval architecture from Late Romanesque to Early Gothic and Early to High Gothic is compatible with the assumptions of typology, a linear pattern of evolution. This does not mean that the typological approach and style analysis, which are major traditional methods of art history, have to be abandoned completely in studying Byzantine architecture. When used properly, typology can be useful in tracing relationships between distant geographies (Ousterhout, 1999, 26). Style analysis, on the other hand, could be very useful for the recognition of the building as an object in its own right and for understanding aesthetic values of societies (Fernie, 2006, 21-2). Criticisms of style analysis usually stem from its overemphasis by some art historians and architectural historians and the danger comes from constructing periods of style for the small number of buildings.

The other traditional method of art history, the biographical approach, is basically exploring a building through the life of its architect (or sometimes its patron). Although the biographical approach has received much criticism in the discipline of art history since 1970s for its exclusion of broader cultural and social context, it has still been widely used in the writing architectural histories, particularly when the architect has been identified as major figure or as genius in the evolution of architectural history (Arnold, 2002, 35-41). Since the identity of architects, or master masons as a more appropriate term, is not known except for a few examples in the Byzantine world, such an analysis would not be applicable in Byzantine architectural history. Rather than individual builders, workshops were identified in some cases (Ousterhout, 1999, 39). Much more is known about the patrons, whose names were put up on inscriptions, and texts tell us more about them. However, writing architectural history based solely on biographical documents runs certain risks of ignoring cultural and political context. For this reason, exploring a building in relation to its designer or patron would be useful when it is considered as one of many diverse ways of examining the history of Byzantine architecture.

Since the emphasis is on the use for which a building was intended and the intentions of the patron, the functional approach can open more directions than the purely typological (Mango, 1991, 43). However, the functional approach may not explain for example, the wide diffusion of the crossin-square church type and its use for a variety of different purposes such as palace churches or burial chapels. Since most buildings of this type are small, it is suited to small scale congregations and it was used for a variety of private foundations either imperial or monastic. Evaluating these small scale cross-in-square buildings, transformations in the liturgy, which was the essential activity carried out in these churches, should be taken into consideration. The privatization of worship during the transitional period is usually assumed to be responsible for the formation of many small-scale churches (Mango, 1985, 249).

This leads us to another realm in studying Byzantine architecture-transformations in society and culture. The assumption of Byzantine society's rigidity and unchangeability stems from the Western European biases due to evaluating Byzantine history in comparison with the political upheavals of medieval Europe. What needs to be emphasized here is the multicultural nature of the Byzantine Empire, which has usually been overlooked by certain art and architectural historians, who have treated it with reference only to Orthodox Christianity. This has again been derived 
18. Fletcher (1961, 272). from Western European preconceptions. This is most evident in the survey textbooks on architectural history. For example, in the different editions of Fletcher's A History of Architecture, it is stated:

"Byzantine architecture, devoid of statutes, has always been remains of the official style of the Orthodox church of Eastern Europe which has conserved unchanged its doctrines and ritual. Therefore architecture also became stereotyped in form through all periods, in sharp contrast with the changes and additions which characterize the developments of medieval architecture to suit it to the varying requirements of church economy and ritual in Western Europe" (18).

Based on the Western European model, expecting a linear pattern of evolution, dramatic structural changes, and grand scale buildings from Byzantine architecture has led to misconceptions of Byzantine architecture as "small, stagnant and dull" (Ousterhout, 1996, 21-2). The evaluation of Byzantine church architecture according to ground plan only has led to ignoring its three-dimensional character. Similarly, overlooking the privatization of worship and transformations in the liturgy during the transitional period may have caused errors in evaluating the "small scale" of the cross-in-square churches. For this reason, in order to overcome such limited perceptions, social and cultural transformations that occurred throughout the long history of the Byzantine Empire need to be more emphasized by architectural historians.

Byzantine architecture had relations with Roman, Late Antique, Syrian, Sassanian, Persian, Umayyad, Abbasid, Armenian, Seljuk, and Ottoman architecture. However, in Byzantine studies, there has been a tendency to ignore possible cross-cultural exchanges. In fact, such neglect has also seen in the Turkish/Islamic perspective of Byzantium. For this reason, the necessity of studying Byzantine architecture in a broader geography, in the medieval Mediterranean context needs to be emphasized. Moreover, employing a cross-cultural comparisons and connections approach will help avoid ethnocentrism and offer an integrated Byzantine architectural history.

The socio-economic and political parameters of building activity should also be taken into consideration. On the other hand, questions such as "How did the Byzantine viewer perceive the church?" bring forth symbolic and cosmological explanations according to which the church could become the image of heaven, of the cosmos. This is most relevant for the churches in Cappadocia for example. Although they were carved, rather than built, and structural elements such as columns and domes were unnecessary, the artists painted columns and domes (Ousterhout, 1999, 24-5). This brings forth another topic, that of the aesthetic qualifications of the buildings and the relationships between architectural form and painted decoration. The decorative program of the interior of the buildings needs to be evaluated within or as part of the architectural integrity, rather than as autonomous art works. Architecture, in turn, was an integral and iconographically significant part of the decorative program. Pointed out by several scholars, in many Byzantine churches there is a direct relationship between architectural form and decoration (Ousterhout, 1996, 28).

As Mango and Ousterhout have stated, today the archaeological approach, which is based on the detailed archaeological analysis of buildings, is the most common way of studying Byzantine architecture. In fact, as mentioned elsewhere, archaeological investigations of Byzantine buildings have been used from the beginning of Byzantine studies in Turkey, since 
19. 18. Araştırma Sonuçları Toplantısı, (22-26 Mayıs, İzmir) Kültür ve Turizm Bakanlığı, Kültür Varlıkları ve Müzeler Genel Müdürlüğü, Ankara. (2000).

20. See 32. Uluslararası Kazı, Yüzey Araştırması ve Arkeometri Sempozyumu (24-28 May 2010, İstanbul) www.kultur.gov.tr/ yuzeyarastırmaları/belge.
Byzantine materials in Turkey were waiting to be "discovered." In line with this approach, there have been growing survey studies on Byzantine architecture in the last decades. An examination of papers presented at the "The International Symposium of Excavations, Surveys and Archaeometry" organized by the Ministry of Culture and Tourism every year shows that studies on Byzantine monuments have recently increased. For example, in 1999 while only 4 field surveys were carried by Turkish scholars (19), in 2009, 10 field surveys were carried out by Turkish scholars solely on the Byzantine period, and 5 include the Byzantine periods (20). However, the increase in the number of survey studies has brought about its own problems. Although these problems are not confined to Byzantine studies alone -and leaving aside the financial concerns- one of them is the fact that many archaeological survey projects are carried out by quite limited teams. For this reason, an interdisciplinary approach including technological equipment and specialized labors are absolutely crucial in field studies of Byzantine architecture.

Another topic that needs more scrutiny in studies of Byzantine architecture is the scarcity of studies focusing on "secular" architecture. As noted by Mango, an assumption is that Byzantine architecture consists of churches and monasteries only (Mango, 1991, 40). The relatively good condition of surviving ecclesiastical architecture due to conversions to mosques, in many cases, has been an important factor in this. However, the disciplinary status of Byzantine architecture could also be a determining factor in this situation. In other words, since Byzantine architecture is mostly incorporated into the discipline of art history in Turkey, its attention had been directed to churches decorated with frescos and mosaics until recently. Although it is encouraging that the study of secular architecture is increasing in recent years, studying houses, fortifications, aqueducts, bridges, etc. needs more rigorous attention.

The point is since its beginnings, the focus of Byzantine studies has been İstanbul first, and then central and west Anatolia. This is also an important issue. Today, it seems that almost no Byzantine studies are carried out in the eastern part of Anatolia. The examination of this region particularly in relation with other cultures such as Armenian architecture would contribute much to the growing body of studies in Byzantine architecture in Turkey.

\section{CONCLUSION}

In the early Republican Period, the history of art and architecture as a discipline emerged pragmatically in the context of nationalism and was intimately related to the Republican project of utilizing historiography for purposes of nation building. In other words, architectural history was utilized to find the roots of the "national architecture" under the influence of nationalism (Bozdoğan, 2002, 262). In this context, the priority of architectural historians was first to establish the essence of the Republican nationalist view of Ottoman and pre-Ottoman Turkish art and architecture. In the general architectural histories of Ottoman- Turkish art and architecture, Byzantine architecture was usually compared with the Turkish architecture to show the architectural superiority of Turkish architecture.

During this period, although there were quite a number of archaeological studies concerning Byzantine monuments carried out mainly by foreign 
scholars, and a small number by Turkish archeologists, these archaeological studies were not carried out systematically. Other studies in Byzantine architecture were confined to a few pages in the general architectural histories of Ottoman or Turkish art and architecture. After the years of 1950-1960, the number and variety of architectural history texts related to Turkish architecture increased considerably. The establishment of a certificate program in Byzantine art history within the department of Art History at İstanbul University paved the way for more systematic researches on Byzantine art and architecture and led to the increase in publications in this field. Moreover, these texts formed the groundwork for the later studies and had an important impact on architectural education. However, it can be said that the Byzantine legacy was not incorporated within the historical evolution of Ottoman and Turkish architectural history in these studies.

Needless to say, studies on Byzantine architecture are not confined to the works mentioned in this paper. There are a number of monographs and archaeological reports written by different archaeologist and art historians. During recent decades, on the other hand, there has been a great increase in the number of studies devoted to the Byzantine architecture. Among different approaches to the study of architecture, the typological approach has been the most common one in studying Byzantine architecture in Turkey. With the increasing survey studies on Byzantine architecture in the last decades, on the other hand, detailed archaeological analysis of buildings has also increased in the study of Byzantine architecture. However, in Byzantine studies, there has been a tendency of ignoring possible cross-cultural exchanges. Byzantine architecture had relations with Roman, Late Antique, Syrian, Sassanian, Persian, Umayyad, Abbasid, Armenian, Seljuk, and Ottoman architecture. For this reason, the necessity of studying Byzantine architecture in a broader geography in the medieval Mediterranean context needs to be emphasized. Moreover, employing a cross-cultural comparisons and connections approach will help avoid ethnocentrism and offer an integrated Byzantine architectural history.

\section{BIBLIOGRAPHY}

ABBASOĞLU, H., BELLİ, O., eds. (1992) İstanbul Yazıları: Semavi Eyice Armağanı, Türkiye Turing ve Otomobil Kurumu Yayını, İstanbul.

AHUNBAY, Z., MAZLUM, D., EYÜPGILLER, K., eds. (1996) Prof. Doğan Kuban'a Armağan, Eren Yayınları, İstanbul.

AKYÜREK, E. (2010) Byzantine Art History in Modern Turkey, in Perceptions of the Past in the Turkish Republic: Classical and Byzantine Periods, eds. Scott Redford, Nina Ergin, Ancient Near Eastern Studies, Supplement 31, Leuven-Paris-Walpole, MA; 205-224.

ALTAN ERGUT, E. (2007) Celal Esad Arseven's History of Architecture Between the Past and Present, Aesthetics Bridging Cultures: XVIIth International Congress of Aesthetics (9-13 July 2007) Middle East Technical University, Ankara.

ALTAN ERGUT, E., TURAN ÖZKAYA, B. (2009) Explorations: Architectural History in Turkey, European Architectural History Network Newsletter (2) http:// www.eahn.org/resources/ uploads/306/Explorations 209 Turkey.pdf 
ALTINYILDIZ, N. (2007) The Architectural Heritage of İstanbul and the Ideology of Preservation, History and Ideology: Architectural Heritage of the Lands of Rum, eds. S.Bozdoğan, G. Necipoğlu, Muqarnas: An Annual on the Visual Culture of the Islamic World (24) Leiden-Boston; 281-305.

ANDERSON, B. (1991) Imagined Communities, Verso, London and New York.

ARNOLD, D. (2002) Reading Architectural History, Routledge, London and New York.

ARNOLD, D. (2006) Beyond a Boundary: Towards an Architectural History of the Non-East, Rethinking Architectural Historiography, eds. D.Arnold, E. Altan-Ergut, B.Turan-Özkaya, Routledge, London and New York; 229-45.

ARSEVEN, C. E. (1909) Constantinople de Byzance á Stamboul, traduit du Turc par l'auteur, Librairie Renouard, H.Laurens, Paris.

ARSEVEN, C. E. (1984) Türk Sanatı, Akşam Matbaası, (1st ed. in 1928), İstanbul.

ATAKUMAN, Ç. (2008) Cradle or Crucible: Anatolia and Archaeology in the Early Years of the Turkish Republic (1923-1938), Journal of Social Archaeology (8) 214-35.

BOYAR, A.S. (1943) Aya Sophia and Its History, İstanbul, Maarif Matbaası.

BOYAR, A.S. (1948) Türk ve Bizans Mimarisine Dair Bir Mukayese, III. Türk Tarih Kongresi (Ankara 15-20 Kasım 1943) Kongreye Sunulan Tebliğler, Türk Tarih Kurumu Basımevi, Ankara:694-700.

BOZDOĞAN, S. (2002) Modernizm ve Ulusun İnşası: Erken Cumhuriyet Türkiyesi'nde Mimari Kültür, Metis, İstanbul.

BOZDOĞAN, S (2007) Reading Ottoman Architecture Through Modernist Lenses: Nationalist Historiography and the "New Architecture" in the Early Republic, History and Ideology: Architectural Heritage of the Lands of Rum, eds. S.Bozdoğan, G. Necipoğlu, Muqarnas: An Annual on the Visual Culture of the Islamic World (24) Leiden-Boston; 199-221.

BOZDOĞAN, S., NECIPOĞLU G., eds. (2007) History and Ideology: Architectural Heritage of the Lands of Rum, Muqarnas: An Annual on the Visual Culture of the Islamic World (24) Leiden-Boston.

CRINSON, M. (1996) Empire Building: Orientalism and Victorian Architecture, London and New York.

ÇIĞ, M. İ. (2009) Atatürk ve Sümerliler, Ankara, Kaynak Yayınları.

DELİLBAŞI, M. (2005) The Present and Future of Byzantine Studies in Turkey, Memory of Nikos Oikonomides, eds. Florentina EvangelatouNotara, Athens-Thessalonica; 63-72.

DIEHL, C. (1937) Bizans Imparatorluğu Tarihi, translated by T. Bıyıkoğlu. İstanbul:Vakit Gazete Matbaa.

DOLUNAY, N. (1948) Çankırı Kapı Höyügü̈, III. Türk Tarih Kongresi (Ankara 15-20 Kasım 1943) Kongreye Sunulan Tebliğler, Türk Tarih Kurumu Basımevi, Ankara:212-218.

ERSANLI-BEHAR, B. (1992) İktidar ve Tarih: Türkiye'de "Resmi Tarih" Tezinin Oluşumu (1929-1937), Afa, İstanbul. 
ESİN, U. (1999) Türkiye Cumhuriyeti'nin 75. Yılında Atatürk Düşüncesinde Ulusal Kimliğin Oluşturulma Sürecinde Arkeolojinin Yeri: Dünü, Bugünü, Türkiye Cumhuriyeti'nin 75. Yılında Bilim "Bilanço 1923-1998" Ulusal Toplantısı, I. /2, TÜBITAK, Ankara; 277-88.

EYİCE, S. (1960) Bizans- İslam- Türk Sanatı Münasebetleri, V. Türk Tarih Kongresi (Ankara 12-17 Nisan 1956) Kongreye Sunulan Tebliğler, Türk Tarih Kurumu Basımevi, Ankara: 298-302.

EYİCE, S. (1973) Türkiye'de Bizans Sanatı Araştırmaları ve İstanbul Üniversitesinde Bizans Sanatı, Cumhuriyet'in 50. Yılına Armağan, İstanbul Üniversitesi Edebiyat Fakültesi Yayınları, İstanbul; 375-428.

EYİCE, S. (1976) Türkiye'de Bizans Mimarisi Hakkındaki Yabancı Araştırmaların Kısa Tarihçesi (İkinci Dünya Savaşına Kadar), Sanat Tarihi Yıllığı, İstanbul Üniversitesi Edebiyat Fakültesi Yayınları, İstanbul; 453-69.

EYİCE, S. (1993) Bir İstanbul Tarihçisi: Mehmed Ziya, İstanbul, Türkiye Tarih Vakf1 Yayınları (6) 121-6.

EYİCE, S. (1971) Karaman (Binbirkilise) ve Karaman Çevresinde Arkeolojik İncelemeler, İstanbul.

EYİCE, S. (1980) Son Devir Bizans Mimarisi: İstanbul'da Palaiologos Devri Anttlar, (1st. ed. 1963), İstanbul.

FERNIE, E. C. (2006) Art History and Architectural History, Rethinking Architectural Historiography, eds. D.Arnold, E. Altan Ergut, B.Turan Özkaya, Routledge, London and New York; 17-24.

FLETCHER, S.B. (1961) A History of Architecture on the Comparative Method, (17th ed.) University of London, Athione Press, London.

FIRATLI, N. (1960) Byzantion Nekropolü ve Son Buluntular, V. Türk Tarih Kongresi (Ankara 12-17 Nisan 1956) Kongreye Sunulan Tebliğler, Türk Tarih Kurumu Basımevi, Ankara; 194-8.

GIBBON, E. (1932) The Decline and Fall of the Roman Empire, New York, Modern Library.

GRENEIER, P. (1904) L'empire Byzantin: son evolution sociale et politique, Paris: Plon-Nourrit.

İNAN, A. (1939) Atatürk ve Tarih Tezi, Belleten III (10) 243-46.

KALAS, V. (2004) Early Explorations of Cappadocia and the Monastic Myth, Byzantine and Modern Greek Studies, (28) 101-19.

KATSARIDOU I., K. BILIOURI, (2007) Representing Byzantium: the Narratives of the Byzantine Past in Greek National Museums, Making National Museums, (26-28 February) Linköping University, http:// www.ep.liu.se/ecp/022/016/ (05.05.2010).

KOÇU, R. E. (1934) Bizans Tarihi: Şarki Roma Imparatorluğu (395-1453), Çocuklara Tarih Kitapları, No: 22, İstanbul.

KÖPRÜLÜ, Fuad (2003) Bizans Müesseselerinin Osmanlı Müesseselerine Tesiri, Kaynak Yayınları, İstanbul.

KUBAN, D. (1965) Anadolu Türk Mimarisinin Kaynak ve Sorunları, İstanbul Teknik Üniversitesi Mimarlık Fakültesi Yayınları, İstanbul. 
KUBAN, D. (1996) İstanbul an urban history: Byzantion, Constantinopolis, İstanbul, The Economic and Social History Foundation of Turkey, İstanbul.

KUBAN, D., et al. (1999) Bizans'ın Mirası Üzerine Tartışma, Cogito, 17, İstanbul Yapı Kredi Yayınları; 376-94.

MANGO, C. (1984) Byzantinism and Romantic Hellensim, in Byzantium and its Image: History and Culture of the Byzantine Empire and its Heritage, Variorum Reprints, London; 29-43.

MANGO, C. (1985) Byzantine Architecture, New York, Rizzoli.

MANGO, C. (1991) Approaches to Byzantine Architecture, Muqarnas (8) K. A. C. Creswell and His Legacy; 40-4.

MANSEL, A. M. (1933) The Excavations of the Balaban Aga Mesdjidi in İstanbul, in The Art Bulletin (15) 210-29.

MEHMED ZIYYA, İHTİFALCİ, (2004), İstanbul ve Boğaziçi: Bizans ve Osmanl Medeniyetlerinin Ölümsiz Mirası C.I-II, E. Doğan and M. Karavelioğlu (yay. haz), Bika, İstanbul.

NECİPOĞLU, N. (2003) Türkiye'de Bizans Tarihçiliğinin Dünü, Bugünü ve Sorunları, Toplumsal Tarih (112) 72-7.

NECİPOĞLU, N. (2009) Byzantine Studies in Turkey: Contemporary Trends in Historical Scholarship, paper presented in the symposium of Contemporary Perceptions of Byzantium on 19-21 November in İstanbul.

OGAN, A. (1948) Küçükçekmece Hafriyatı ve Rhegion Sarayı, III. Türk Tarih Kongresi (Ankara 15-20 Kasım 1943) Kongreye Sunulan Tebliğler, Türk Tarih Kurumu Basımevi, Ankara; 537-43.

OGAN, A. (1952) Pammakaristos (Fethiye Camii), IV. Türk Tarih Kongresi (Ankara 10-14 Kasım 1948) Kongreye Sunulan Tebliğler, Türk Tarih Kurumu Basımevi, Ankara; 407-14.

OUSTERHOUT, R. (1996) Apologia for Byzantine Architecture, Gesta (35: 1) 21-33.

OUSTERHOUT, R. (1999) Master Builders of Byzantium, Princeton University Press, Princeton, N.J.

ÖGEL, S., ed. (2004) Metin Ahunbay'a Armağan: Bizans Mimarisi Üzerine Yazılar, Sanat Tarihi Defterleri (8) Ege Yayınları, İstanbul.

ÖTÜKEN, Y. (2003) Türkiye' de Bizans Sanatı, Toplumsal Tarih (112) 78-9.

ÖZDEMIR, A. (2003) Hayali Geçmiş: Arkeoloji ve Milliyetçilik 1923-1945 Türkiye Deneyimi, Arkeoloji: Niye? Nasil? Ne için? eds. Oğuz Erdur and Güneş Duru, Ege Yayınları, İstanbul; 7-26.

ÖZDOĞAN, M. (1998a) Ideology and Archaeology in Turkey, Archaeology Under Fire: Nationatilism, Politics, and Heritage in the Eastern Mediterranean and Middle East, ed. Lynn Meskell, Routledge, London and New York; 111-23.

ÖZDOĞAN, M. (1998b) Türkiye Cumhuriyeti ve Arkeoloji: Siyasi Yönlendirmeler-Çelişkiler ve Gelişim Süreci, Bilanço:1923-1998:

Türkiye Cumhuriyeti'nin 75 Yılına Toplu Bakış Uluslararası Kongresi, (I: Siyaset, Kültür, Uluslararası İlişkiler), ed. Zeynep Rona, Tarih Vakfı Yurt Yayınları, İstanbul; 193-204. 
ÖZDOĞAN, M. (2004) Heritage and Nationalism in the Balkans and Anatolia: What Has Happened since Hasluck?, Archaeology, Anthropology and Heritage in the Balkans and Anatolia: The Life and Times of F.W. Hascluck, 1878-1920, eds. D. Shankland, Vol.2, The Isis Press, İstanbul; 389-407.

PULHAN, G. (2004) Cumhuriyet'in Arkeoloji Seferberliği, Sanat Dünyamız (89) $171-4$.

RABAT, N. (2005) Toward an Intercultural Historiography of Islamic Architecture, Changing Boundaries: Architectural History in Transition, SAH 2nd International Conference at the Institut National d'Histoire de l'Art (INHA), Paris, www.inha.fr/colloques/document. php?d=642 (04.04.2010)

RAMAZANOĞLU, M. (1952) Yeni Araştırmalara Göre Sent İren ve Ayasofya'lar Manzumesinin Değişen Mimari Tarihi, IV. Türk Tarih Kongresi (Ankara 10-14 Kasım 1948) Kongreye Sunulan Tebliğler, Türk Tarih Kurumu Basımevi, Ankara; 80-93.

STRIKER, C. L. (2001) The Findings at Kalenderhane and Problems of Method in the History of Byzantine Architecture, Byzantine Constantinople: Monuments, Topography and Everday Life, ed. N. Necipoğlu, Brill, Leiden, 107-17.

TANYERİ-ERDEMİ, T. (2006) Archaeology as a Source of National Pride in the Early Years of the Turkish Republic, Journal of Field Archaeology (31:4) 381-93.

TEXIER, C. (2002) Küçük Asya Coğrafyası, Tarihi ve Arkeolojisi, trans. by A.Suat, Ankara: Enformasyon ve Dokümantasyon Hizmetleri Vakfı.

URSİNUS, M. (1986) Byzantine History in Late Ottoman Turkish Historiography, Byzantine and Modern Greek Studies (10: 1) 211-22.

URSIINUS, M. (1987) Der schlechteste staat: Ahmed Midhat Efendi (18441913) on Byzantine Institutions, Byzantine and Modern Greek Studies (11:1) 237-44.

URSİNUS, M. (1988) From Süleyman Pasha to Mehmet Fuat Köprülü: Roman and Byzantine History in Late Ottoman Historiography, Byzantine and Modern Greek Studies (12: 1) 305-14.

VASILIEV, P. (1943) Bizans Imparatorluğu Tarihi, translated by A. M. Mansel. Ankara:Maarif Matbaası.

YILDIRIM, M. (Söyleşi) (2007) Bir Rönesans Adamı: "Doğan Kuban Kitabı", Türkiye İş Bankası Kültür Yayınları, İstanbul.

X. Milletlerarası Bizans Tetkikleri Kongresi Tebliğleri (1978), (15-21 Eylül 1955, İstanbul), Nendeln/Liechtenstein. 
Alınd1: 05.08.2010; Son Metin: 18.10.2011

Anahtar Kelimeler: Bizans çalışmaları; kültür politikaları; mimarlık tarihyazımı.

\section{TÜRKIYYE'DE BİZANS ÇALIŞMALARI VE MİMARLIK TARİHİ YAZIMI}

Cumhuriyet'in ilk yıllarında, yeni kurulan ulus devletin meşruiyetini sağlamak ve ortak bir kimlik yaratmak için arkeolojik ve tarihsel mirasa sahip çıkmak önem kazanmıştır. Bu dönemde, Anadolu'da yaşayan en eski uygarlıkların, "milli" kültürel mirasın bir parçası olarak algılanması ve tanımlanması sürecinde, Bizans'ın nasıl bir rol oynadığı sorusu önem taşımaktadır.

Son yıllarda Türkiye'de, Bizans kültürel mirasının, tarih, edebiyat, hatta bilim ve sanattaki temsili üzerine yapılan çalışmaların sayısı artmıştır. Ancak, erken Cumhuriyet dönemi ve sonrası mimarlık tarihi yazımı üzerine olan çalışmalarda, Bizans mimarlığı ya da Osmanlı ve Cumhuriyet Dönemi mimarlık tarihi içinde Bizans mirasının yeri üzerine olan çalışmalar yok denecek kadar azdır.

Bu makalenin amacı, erken Cumhuriyet dönemi ve 1950 yılı sonrasındaki tarihsel gelişmeler ve kültür politikaları bağlamında, Türkiye' de yapılan Bizans çalışmalarının kısa bir tarihini sunmak ve bu dönemdeki Bizans mimarlık tarihi yazımının değerlendirilmesine bir giriş yapmaktır. Bu değerlendirmede, hem doğrudan Bizans mimarisi üzerine yapılan çalışmalar, hem de erken Cumhuriyet dönemi sanat ve mimarlık tarihçilerinin Bizans mimarlı̆̆ına yaklaşımları ile Osmanlı ve Cumhuriyet mimarlığının tarihsel gelişiminde Bizans mirasını ne dereceye kadar dâhil ettikleri sorusunu irdelemek amaçlanmıştır.

Son olarak, Bizans mimarlık tarihi yazımındaki metodolojik yaklaşımlar genel olarak değerlendirilmeye çalışılmıştır. Bu kapsamda, sanat tarihinin geleneksel yöntemlerinden tipoloji çalışmalarının giderek ağırlığını kaybettiği, artan arkeoloji çalışmalarıyla birlikte, Bizans'ın bin yıllık tarihi boyunca yaşanan politik, dini, toplumsal, ekonomik ve sanatsal gelişmelerin daha fazla dikkate alındığı gözlenmiş olup, Bizans'ın çok kültürlü yapısına vurgu yapan ve onu daha geniş bir coğrafi ve tarihi bağlam içerisinde değerlendiren çalışmalara gereksinim duyulduğu belirtilmiştir.

Şule KILIÇ YILDIZ; BA, MA.

Graduated from the department of Art History at İstanbul University (2001), where she later received MA degree (2004). Currently a Ph.D. student in History of Architecture at METU. Employed in the General Directorate of Cultural Artifacts and Museums, Ankara, Turkey. kilicsule@yahoo.com 